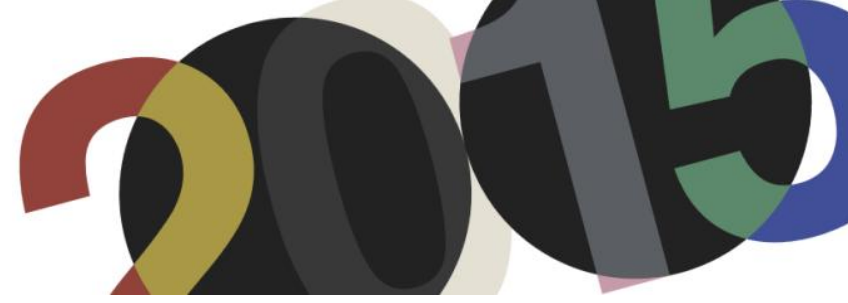

DOI: http://dx.doi.org/10.4995/LC2015.2015.1033

\title{
In Quest of Modernity: Le Corbusier's Project for the New Civic Hospital in Venice
}

\author{
I. Tolic
}

University of Bologna

\begin{abstract}
The paper deals with Le Corbusier's unbuilt project for Venice analyzing the meaning of the Civic Hospital within the cultural context between 1954, the year in which the new master plan started to take shape, and 1966, when an extraordinary 'acqua alta' put an end to city's contemporary ambitions. In Venice's quest for modernity, the master plan (1954-1962), the national competition for the San Giuliano district (1959), the national competition for the Hospital (1963) and the international one for the Tronchetto Island (1964-1965) represent key events in which conservatives and modernists found themselves face to face, and in relation to which Le Corbusier's project has not yet been studied. Even though Le Corbusier's Hospital was presented to the public opinion as a courageous and innovative project, this paper seeks to demonstrate that it was actually more in line with the conservative front because it brought back the "problem of Venice" to its insular dimension after more than a decade of attempts to solve it considering a wider regional frame.
\end{abstract}

Resumen: El articulo trata sobre el proyecto, no cumplido, por Le Corbusier para Venecia incluyéndolo en el contexto cultural desarrollado entre el año 1954, en el que el nuevo master plan empezaba a coger forma, y el 1966, cuando una extraordinaria 'acqua alta' cortó los anhelos de modernidad del tiempo. Los acontecimientos clave de este periodo fueron: el master plan, el concurso nacional para el barrio de San Giuliano, el concurso nacional para el Hospital y el concurso internacional para la Isla de Tronchetto. Con respecto a estos el proyecto de Le Corbusier no había todavía estado analizado. El Hospital de Le Corbusier había estado presentado, en su tiempo, como un proyecto innovador. Lo que este articulo quiere demostrar es que, en realidad, representó una posición conservadora, pues volvió a llevar el problema de Venecia en sus medidas insulares después de mas diez años de intentos para solucionarlo a escala regional.

Keywords: Venice; Civic Hospital; Le Corbusier; modernity; center and periphery. Palabras clave: Venice; Civic Hospital; Le Corbusier; modernidad; centro y periferia.

\section{Introduction}

In the last five decades, life and work of Le Corbusier have been analyzed from many and different points of view. The considerable amount of publications - impossible to summarize - demonstrates on one side the richness of his accomplishments and on the other, the never abating interest of scholars towards them. Among publications and events dedicated to Le Corbusier only in the last years, it might be worth mentioning the exhibition which took place at Museo Nazionale delle Arti del XX Secolo [MAXXI] in Rome, which investigated architect's relationship with Italy throughout his career ${ }^{1}$. For however long and articulated, it was only in the last phase of his productive life that Le Corbusier got the chance to work in the country, even though none of his projects was accomplished. In fact, he was commissioned a Church in Bologna (1962), the Olivetti Electronic Center in Rho $(1963)^{2}$ and the Civic Hospital in Venice ${ }^{3}$. The last project has attracted the interest of scholars which have investigated it thoroughly probing its assonances with the earlier formulations of the

\footnotetext{
${ }^{1}$ Talamone, Marida (Ed.): L'Italia di Le Corbusier (exhibition catalogue: Rome, October 18, 2012 - February, 17, 2013). Milan: Electa, 2012.

${ }^{2}$ Bodei, Silvia: Le Corbusier e Olivetti. La Usine Verte per il Centro di calcolo elettronico. Macerata: Quodlibet, 2014.

${ }^{3}$ Gresleri, Giuliano; Gresleri, Glauco: Le Corbusier. Il programma liturgico. Bologna: Compositori, 2001.
} 
"musee à croissance illimitée", ; analyzing it as an epitome of the "mat-building" type"; attempting to identify its origin in relation to a wider international contemporary architectural discourse ${ }^{6}$; or studying its structural formulation in comparison to the medieval urban configuration of the city of Venice ${ }^{7}$ - to mention just a few. What still seems to be missing is an attempt to analyze the meaning of Le Corbusier's project for and within contemporary Italian cultural context. The project for the Civic Hospital in fact belongs to a period which saw the national competition for the new masterplan of Venice (1954-1962), the national competition for the residential district of San Giuliano in Mestre (1959), the national competition for the new Civic Hospital (1963) and the international one for Tronchetto Island (1964-1965). In each of these competitions, architects and urban designers tried to solve the so-called "problem of Venice", and namely the problematic relationship between the historical center and its urban expansions on mainland. Which was Le Corbusier's role within these debates and in relation to the very future of Venice? Why, in spite of the national competition for the new Civic Hospital, he was assigned the task? And, even more relevant, what this choice and his presence in Venice meant within that period?

The following paper is also a part of a larger research dealing with the Civic Hospital of Venice and a rich series of unbuilt or partially built projects which characterize its history between the end of the Republic (1797) and today. On one side, unbuilt projects reveal about clients' aspirations as much as any built structure (and possibly even more due to their existence only on paper). On the other side, the surprising number of proposals prepared for the Civic Hospital allows us to consider the ever evolving relationship between health care and architecture to the study of which Le Corbusier's project and the national competition for San Giobbe offers material for further deepening. Moreover, the history of the Civic Hospital is strongly interwoven with Venice's quest for modernity, in relation to which Le Corbusier's project assumes a particular meaning. In fact, instead of considering it as a part of a series of unbuilt projects for Venice ${ }^{9}$, the goal of this paper is to reverse the point of view thus explaining the meaning of the Hospital in relation to the debates which made the proposal possible and which are to be intended as attempts to solve the above mentioned "problem of Venice". Even though the choice of Le Corbusier was presented to the public opinion as a courageous act aimed at city's modernization, the paper seeks to demonstrate that, aside contemporary propaganda, the Hospital affaire has actually an extremely complex background. By bringing back the "problem of Venice" to its insular dimension (after more than a decade of attempts to consider it within a wider regional frame), Le Corbusier's project reconciled two opposite visions of the future of Venice bypassing one of the most pressing issues discussed within the national cultural scene, and namely the conflicting relationship between historical centers and new peripheries.

\footnotetext{
${ }^{4}$ O’Byrne Orozco, María Cecilia. El proyecto para el hospital de Venecia de Le Corbusier. Director: Josep Quetglas. Universidad Politécnica de Cataluña, Escuela Superior de Arquitectura de Barcelona, 2007.

${ }^{5}$ Sarkis, Hashim (Ed.), Le Corbusier. Venice hospital and the Mat building revival. Munich: Prestel, 2002.

${ }^{6}$ Reichlin, Bruno: "L'Ospedale di Venezia. Congetture sulla genesi del progetto". En Talamone, Marida (Ed.): L'Italia di Le Corbusier (exhibition catalogue: Rome, October 18, 2012 - February, 17, 2013). Milan: Electa, 2012. pp. 390-409.

7 Shah, Mahnaz: Le Corbusier's Venice Hospital Project. An Investigation into its Structural Formulation. Farnham: Ashgate, 2013.

${ }^{8}$ Comune di Venezia; Fondazione Giorgio Cini: Atti del Convegno internazionale "Il problema di Venezia". Venice: w/o.pub, 1964.

${ }^{9}$ Puppi, Lionello; Romanelli, Giandomenico (Ed.): Le Venezie possibili: da Palladio a Le Corbusier. Milan: Electa, 1985.
} 


\section{Le Corbusier and "the problem of Venice"10}

Towards mid-1960s, a series of debates and discussions about the future of Venice has created an increasingly tense atmosphere which was about to result in an open conflict between conservators and innovators. Precisely before that moment, between April 8 and 14, 1965, Le Corbusier visited the lagoon for the second time since the beginning of the Hospital affaire and his permanence was recorded by the Italian National Television (RAI) ${ }^{11}$. The video represents a rare document in which the project was explained for the benefit of non-specialists and in which the issue at stake was defined by the very protagonists of the story.

Le Corbusier was interviewed while standing on Saint Mark square, having the church of San Giorgio Maggiore, designed by Andrea Palladio, as a background. The choice of the location allows a suggestive interpretation, creating a symbolic link between the old master, who centuries ago left his unmistakeable mark on the city, and the new one, ready to embark on a similar task. Le Corbusier said: "All the beauties of Venice are already known. But what will happened with Venice within the contemporary internationalization processes? I think it is extremely necessary to find a way to preserve the physical, spiritual and intellectual unity which has determined its history" ${ }^{\prime 2}$. What emerges from these words is a concern towards Venice's future, and an operative indication. According to these words, the new Hospital of Venice may be seen as Le Corbusier's answer to debates regarding the relationship between modern architecture and the historical context.

Within the same video document in fact, Giuseppe Mazzariol explained to the audience that the project for the new Hospital had "unanimously been interpreted as an example of innovation that respects the history and the art of Venice". The hospital was to replace the Slaughterhouse - "a small neoclassical building" - and a "complex of houses built at the beginning of the 20th Century located on the other side of Rio di San Giobbe. It will stretch out into the lagoon on pilotis for 60 meters [...]. There, there will be a sort of dam at the end of which a small chapel will be built. The chapel will be the first thing that those arriving in Venice from terraferma will see". The project, "that harmoniously interacts with city's urban tissue, represents Le Corbusier's own interpretation of Venice. He has been able to renounce completely to his architectural language. [...] He has renounced to everything in order to give us an architecture made entirely of open spaces and in fact, through the pilotis, it will be possible to see Venice [...]. Le Corbusier, who has always built in height, has now designed a small, low and humble architecture which is in perfect harmony with the city. In other words, he was influenced by the city [...] just like Longhena and Palladio before him "13. The tune of the interviews following Mazzariol's speech are more or less the same, stressing the affinities between the project for the Hospital and the city, constantly reassuring the national audience that no damage will be done and that the city could only benefit from Le Corbusier's project.

The video document deals then with a different topic, focusing on the problems of the Hospital hosted within the monumental complexes of San Zanipolo. The discussion revolves around the rapid evolution of medical science and the impossibility to adopt further the preexisting buildings to contemporary health care standards. From this point of view, Le Corbusier's project was presented as innovative given that "the new hospital reserves for each patient an individual cell in which he will be cured far from any sort of degrading and mortifying promiscuity. In

\footnotetext{
${ }^{10}$ Comune di Venezia; Fondazione Giorgio Cini: Atti del Convegno internazionale "Il problema di Venezia". Venice: w/o.pub, 1964.

${ }^{11}$ Ciacci, Leonardo (Ed.): Venezia è una città. Un secolo di interpretazioni del cinema documentario. Venice: Marsilio, 2004. pp. 53-61.

${ }^{12}$ Ibid, p. 53.

${ }^{13}$ Giuseppe Mazzariol. En Pellegrini, Glauco: Servizio sulla presentazione del progetto di Le Corbusier per il nuovo Ospedale di Venezia, "L’Approdo", RAI, May 11, 1965.
} 
the history of architecture and in that of hospitals, Le Corbusier's project - labeled as the modern machine for healing - opens an entirely new chapter "14.

"But will Venice find help and support for the realization of such an important work, which can solve all the inconveniences and chronic shortcomings of an inadequate health care system?" the voice-over asks rhetorically. The answer is provided by Giovanni Favaretto Fisca, the mayor of Venice, who said that "the city administration has already done its job. And I think that the institution I represent will continue to do it also in future . 15 . The president of the Hospital Carlo Ottolenghi, on the other side, mentioned the fact that there might problems with the bureaucratic iter, which is particularly complex: "I keep on my bedside table the Old and the New Testament, but also a list of authorizations that my secretary has prepared and that are necessary for accomplishing the project" $" 16$. In fact, a long list of unbuilt projects prepared for the Hospital during the previous decades testifies the difficulties that the Hospital administration had already encountered and which were now imposing a cautious approach.

As for the architectural and urban qualities of Le Corbusier's project, the video document reports the opinion of Giuseppe Samonà who stated that "this work of art irradiates with balance and meanings so high that it creates an environment within the environment, without ever imposing itself. It creates a new balance and harmony. And when it comes to somebody who is ingenious like Le Corbusier, this harmony has been reached with such understanding of all historical architectures of Venice that it is astonishing. You understand that [...] this project will grow and gradually irradiate a new harmony that this urban tissue needs in order to renew itself with modern vigor [...] "17. Again, the audience was reassured: the Hospital was designed in full respect of Venice's character, and thus there was no need to fear any unwanted consequence.

The RAI registration is an important document which bears witness of the opinion of all parties involved in the Hospital affair. However, what the document doesn't explain is the caution of the interviewed, the too frequent references to the historical character of Venice and the contemporary cultural context. In order to understand that, it is necessary to take into consideration a wider chronological span which allows for a better comprehension of the meaning of the project in relation to the so-called "problem of Venice".

\section{The new master plan and the role of Venice within}

In 1954, the Ministry of Public Works published a list of cities which - according to Article 8 of the Planning Law of 1942 - were obliged to define and adopt a new master plan within five years ${ }^{18}$. Venice was among those cities and was, two years later, also at the center of a legislative action aimed at preserving its monumental character: the so-called Special Law for Venice defined ways in which private and public funds could be

\footnotetext{
${ }^{14}$ Ignazio Muner. En Pellegrini, Glauco: Servizio sulla presentazione del progetto di Le Corbusier per il nuovo Ospedale di Venezia, "L’Approdo", RAI, May 11, 1965.

${ }^{15}$ Giovanni Favaretto Fisca. En Pellegrini, Glauco: Servizio sulla presentazione del progetto di Le Corbusier per il nuovo Ospedale di Venezia, "L’Approdo", RAI, May 11, 1965.

${ }^{16}$ Carlo Ottolenghi. En Pellegrini, Glauco: Servizio sulla presentazione del progetto di Le Corbusier per il nuovo Ospedale di Venezia, "L’Approdo", RAI, May 11, 1965.

${ }^{17}$ Giuseppe Samonà. En Pellegrini, Glauco: Servizio sulla presentazione del progetto di Le Corbusier per il nuovo Ospedale di Venezia, "L’Approdo", RAI, May 11, 1965.

${ }^{18}$ Approvazione del primo elenco dei Comuni obbligati a redigere il piano regolatore dei rispettivi territori. Gazzetta Ufficiale della Repubblica Italiana. № 120. May 26, 1954. Rome: Istituto Poligrafico dello Stato. p. 1621.
} 
synergically used in order to solve urgent hygienic and maintenance problems the city was facing ${ }^{19}$. The two actions are to be intended not as independent from each other, but as a result of a larger concern regarding on one side the preservation of historical and artistic heritage of the past and on the other the future of it, in relation to the role of the city within a larger territorial context. In fact, the new master plan would result in the first planning document to take into consideration both the historical center and its counterparts on terraferma ${ }^{20}$.

At the time the above mentioned laws were published, Venice was already discussing the possibility to hold an international competition for the new master plan and had already invited individual experts to join a special Commissione Redazionale that was asked to prepare the necessary documentation ${ }^{21}$. However, two years later, in June 1956, probably because of the delicacy of the argument but certainly because of the limited time available, the participation was allowed only to national planners who were given 120 days to prepare their proposals ${ }^{22}$. On September 10 of the same year, the participants were given 99 more days being the new deadline postponed to January 15, 1957. Roberto Tognazzi, the major of Venice, stressed several times the importance for Venice to rethink its role within the larger geographical context: "Venice suffers a crisis because of the needs born out from the modern development, and because the limits of its historical center make it impossible for the city to host necessary services and infrastructures. That's why the city has expanded towards terraferma and the estuary, and hence today the need to guide this development transforming this expansion into [...] a vital element for the city thanks to which the historical center will be able to articulate and improve itself within and for the modern society",23.

The Jury ${ }^{24}$ decided to award five proposals (among the 13 presented), assigning the first prize to a group led by Giorgio Amati. The second prize went to a group led by Giovanni Astengo, the third to that led by Daniele Calabi, the fourth to that led by Ludovico Quaroni and the fifth to Lavinio Bellemo. It was Jury's opinion that each of these proposals presented a number of interesting solutions especially regarding the relationship between the center and terraferma. The task to prepare a definitive version of the masterplan was assigned to the before mentioned Commissione Redazionale ${ }^{25}$, the members of which comprised among others Giuseppe Samonà and

\footnotetext{
${ }^{19}$ Provvedimenti per la salvaguardia del carattere lagunare e monumentale di Venezia attraverso opere di risanamento civico e di interesse turistico. Gazzetta Ufficiale della Repubblica Italiana. № 103. April 28, 1956. Rome: Istituto Poligrafico dello Stato.

${ }^{20}$ Back in 1954, the planning tools Venice could count on were a Piano Regolatore del Quartiere Urbano di Marghera dating back to 1926, a Piano di Ricostruzione di Mestre (1950), a Piano di Risanamento di Venezia Insulare (1939), and a never adopted Piano regolatore dell'Abitato di Mestre $(1939,1942)$. Consiglio Comunale: Resoconto Stenografico della Seduta. Relazione Dorigo. February 14, 1958. Archivio Storico Comunale, Venezia. p. 1.

${ }^{21}$ Elementi per il concorso internazionale per il piano urbanistico. February 22, 1954. 1948/X-1-2. Archivio Storico Comunale, Venezia.

${ }^{22}$ Comune di Venezia: Concorso nazionale di idee per la impostazione del piano regolatore generale del Comune di Venezia. June 9, 1956. 1948/X-1-2. Archivio Storico Comunale, Venezia.

${ }^{23}$ Relazione del Sindaco Avv. Roberto Tognazzi nella seduta del 26 ottobre 1956 sul programma dell'Amministrazione Comunale per il quadriennio 1956-1960. Archivio Storico Comunale, Venezia.

${ }^{24}$ Members were Roberto Tognazzi, Gino Luzzatto, Giuseppe Samonà, Attilio Vismara, Wladimiro Dorigo, Giovanni Padoan, Edoardo Detti, Gino Greggio, Armando Melis, Antonino Rusconi, Cesare Valle, Giovanni Bazzuoli, Giuseppe Befani, Giovanni Stecconi, Giuseppe Caporioni, Pietro Zampetti, Ugo Boffa as reported in Approvazione del Piano Regolatore Generale del Comune di Venezia. March 20, 1965. Consiglio Comunale. Archivio Storico di Venezia, Venezia. p. 2.

${ }^{25}$ Commissione was formed on December 14, 1956 with the goal to "prepare a general program for the restoration of the historical center, indispensable both for the master plan and for the detailed plan (piano particolareggiato) that the Municipality had to present according to art. 4 of the new Special Law for Venice". Members were Roberto Tognazzi, Armando Gavagnin, Giuseppe Samonà, Innocenzo Gasparini, Luigi Piccinato, Virgilio Vallot, Benedetto Panciera, Bruno Venturini, Giovanni Padovan, Mario Nono, Pietro Torta, Wladimiro Dorigo, Giorgio Zecchi, Raoul Sartorio, Giovanni
} 
Luigi Piccinato. The drafting process was paralleled with passionate debates in the City Council ${ }^{26}$, in spite of which works were concluded in 1959. Commissione stated in its report that any alterations of the historical center should be avoided, except for the 19th Century areas, in which it was necessary to intervene "in order to provide form and content to the historical center itself" ${ }^{27}$. Among these areas, Commissione identified also the North-Western front of Venice (San Giobbe, Baia del Re and Sant'Alvise), e.g. the areas in which the new Hospital was to be located. In fact, Commissione described the existing Hospital at SS. Giovanni e Paolo as a complex in which "all the services are concentrated in old buildings, and therefore the Hospital can not be considered neither adequate nor efficient; the irrational location of services and the impossibility to restructure the complex in modern terms provides an inadequate response to contemporary necessities" ${ }^{, 28}$. Commissione identified the area of San Giobbe ("well exposed, healthy and immune to toxic fumes" ${ }^{\text {"29) }}$ as an adequate location for the construction of a modern Hospital with a capacity of 1.000 beds.

The final version of the master plan, approved by the local authorities on the 20th of March 1959 and by the national Ministry of Public Works on the 17th of December 1962, affirmed the regional dimension of Venice by setting some main goals to be achieved: a new touristic district was to be accomplished on Punta Sabbioni; a new housing district for 35.000 inhabitants was to be built on mainland, in the area of San Giuliano; a new industrial district was to be located near Porto Marghera; a brand new business district was to be hosted in the area comprised between Piazzale Roma and the Giudecca Canal (considered at that time "the trump card of the masterplan ${ }^{, 30}$ ); and a new Hospital was to be built on the area of San Giobbe ${ }^{31}$. The goals set by the master plan envisioned a reorganization of the city within a regional frame, providing the areas around Ponte della Libertà on its both ends with a brand new role: these were meant to "free" the historical center from its insular dimension triggering at the same time a process of integration between the historical center and terraferma. In fact, it was precisely these areas that future competitions took into consideration.

\section{Le Corbusier's message to the city administrators: "Don't kill Venice"32}

About the time the new masterplan of Venice was ready (October 1962), an international seminar was organized on the island of San Giorgio Maggiore with the aim to find a solution to "the problem of Venice",33. The goal of the seminar was, as declared in the opening speech of the mayor, "to bring to the attention of the world the problems of Venice" because it "is not only an Italian problem, but of all those who believe in the destiny and the universal values of humankind" 34 . The occasion was described by the local press as "a consultation of

Stecconi, Giuseppe Caporioni, Pietro Zampetti, Giuseppe Stomeo and Marcello Maggia. Consiglio Comunale: Resoconto Stenografico della Seduta. Relazione Dorigo. February 14, 1958. Archivio Storico Comunale, Venezia. p. 22.

${ }^{26}$ Comune di Venezia: Piano Regolatore Generale. Relazione. Venezia: w/o, 1959. p. 47.

${ }^{27}$ Ibid, p. 38.

${ }^{28}$ Ibid, p. 40.

${ }^{29}$ Ibid, p. 136

${ }^{30}$ Consiglio Comunale: Resoconto Stenografico della Seduta. Relazione Dorigo. February 14, 1958. Archivio Storico Comunale, Venezia. p. 24.

${ }^{31}$ Ospedali Civili Riuniti: I progetti preliminari per il nuovo ospedale di Venezia. Venezia: Stamperia di Venezia, 1964. s.p.

${ }^{32}$ Le Corbusier: Letter to Giovanni Favaretto Fisca, October 3, 1962. En Comune di Venezia; Fondazione Giorgio Cini: Atti del Convegno internazionale "Il problema di Venezia". Venice: w/o.pub, 1964. pp. 491-493.

${ }^{33}$ Comune di Venezia; Fondazione Giorgio Cini: Atti del Convegno internazionale "Il problema di Venezia". Venice: w/o.pub, 1964.

${ }^{34}$ Favaretto Fisca, Giovanni: "Saluto del sindaco di Venezia". En Comune di Venezia; Fondazione Giorgio Cini: Atti del Convegno internazionale "Il problema di Venezia". Venice: w/o pub, 1964. p. 4. 
international doctors around a patient of great importance ${ }^{, 35}$. Within the title of the congress may be found all the preoccupations about the future of Venice which have exponentially grown since the new masterplan has started to take shape. The city was undoubtedly going through a particularly delicate period, but it has also to be mentioned that the debates about the future of Venice were perfectly in tune with contemporary ongoing international debates, which saw experts engaged in discussions about the future of historical centers in general: the National Congress on Preservation and Renewal of Historical Centers in Gubbio (1960), the International Seminar on Urban Renewal organized by the European Comité de l'Habitat in Geneva (1961) and the International Congress on the Enhancement of Monuments organized by the Fédération Internationale pour l'Habitation, l'Urbanism et l'Aménagément des Territoires in Santiago de Campostela (1961) are only some of the occasions in which the topic was addressed and which took place around the same period. The Venetian congress, organized at Fondazione Cini, is therefore to be understood as a part of this larger national and international debate, within which the case of Venice was particularly significant due to its peculiar urban condition. It would be impossible to summarize all the speeches given during the congress, but it may be interesting to recall the words of Giuseppe Samonà, one of the authors of the master plan, who invited the general public to finally "acknowledge city's regional dimension" and therefore "treat the problems within that larger context",36.

If we attempt to judge the event by looking only at the names of those that were present, and the list of which was published on the first pages of the conference proceedings, than we would surely deduce that the event was a huge success. But there was also an absentee, the participation of which would have been particularly significant: Le Corbusier in fact had kindly declined the invitation to attend the meeting but sent un message, in which Venice was described as "Ville Sacrée", "ville fermée”, "le plus prodigious évènement urbanistique existent sur terre" and "ville harmonieuse". These epithets of the city appear somehow in contrast with the second part of the letter, in which Le Corbusier stated: "Ce que vous avez à reconstruire, faites-le d'une architecture la plus moderne possible. [...] Employez le béton armé pour établir ces standards et ne cherchez pas à copier la vieille brique faite à la main du vieux Venise. Vous pouvez metro au monde des frères et sours des 'Palais Ducals', 'Procuraties', etc. etc. ... de la famille illustre de Venise: des lieu et des locaux (des vases accueillant les functions ou des êtres vivants) ${ }^{\prime 37}$. Le Corbusier's words were addressed to both conservators and modernists: in fact, while affirming city's uniqueness and untouchability on one side, he was also inviting the audience to accept modernity as an unavoidable part of Venice's future. With this message, the architect probably prepared the ground for himself, avoiding momentarily to take part in the discussions. In order to understand the calibrated sharpness of Le Corbusier's words, it is necessary to look at the proposals that were presented for the city around the same period and to understand how the problem of Venice was dealt with by national planners.

\footnotetext{
${ }^{35}$ Ivi. p. 3.

${ }^{36}$ Samonà, Giuseppe: "Centro storico e centro direzionale. Città insulare e terraferma". En Comune di Venezia; Fondazione Giorgio Cini: Atti del Convegno internazionale "Il problema di Venezia". Venice: w/o pub, 1964. pp. 103-111.

${ }^{37}$ Le Corbusier: Letter to Giovanni Favaretto Fisca, October 3, 1962. En Comune di Venezia; Fondazione Giorgio Cini: Atti del Convegno internazionale "Il problema di Venezia". Venice: w/o pub, 1964. p. 492.
} 


\section{Three competitions and some (unaccomplished) solutions to the problem of Venice}

On May 15, 1959, a national competition for a residential neighborhood to be built on San Giuliano's barene (salt marshes) was held ${ }^{38}$. The competition was organized by the Comitato di Coordinamento dell'Edilizia Popolare, who asked planners for a urban district provided with all the necessary civic services. The operation was aimed at managing the flight from Venice towards Mestre, a flight mainly due to the precarious condition of Venetian houses which in the previous decades had resulted in an uncontrolled urban expansion on terraferma. In order to provide directions for further growth, it had become mandatory to configure a comprehensive urban plan and initiate a dialogue regarding the housing problem which interested both the mainland and its insular counterpart $^{39}$. Fifty-seven planners took part in the competition, among which Luigi Piccinato, Giuseppe Samonà, Giovanni Astengo, Ludovico Quaroni as well as the winner: Saverio Muratori ${ }^{40}$. While the latter attempted to configure the new urban complex looking for inspiration at the historical center, the other planners accepted the "vitality of the task",41 offering with their proposals a significant contribution to another problem, and namely "the industrial squalor of Mestre" ${ }^{42}$. Ludovico Quaroni and his team had probably more clearly than others put Mestre in the condition to face the historical center without subjection. The proposal was brave and touched some of the most delicate issues of the contemporary debates regarding the housing problem and, above all, the relationship between historical centers and new peripheries. With the semi circular forms of the business district to be located on the lagoon banks, Quaroni attempted to imposed a new formal configuration to the entire area which comprised 2600 residential units. The project was characterized by a strong internal formal coherence, thus opening a dialogue with both the existing settlements on terraferma and the historical center itself. In other words, Quaroni's proposal embodied a urban discourse in which the regional dimension of Venice was acknowledged ${ }^{43}$ highlighting the need for "an active and dynamic interpretation of each new urban settlement, to be intended as an element of an all-comprehensive urban system ${ }^{, 44}$.

\footnotetext{
${ }^{38}$ Ministero dei lavori pubblici: Quartieri coordinati. Rome: Editalia, 1960. pp. 106-110. See also Dolcetta, Bruno: "Edilizia pubblica, città piano". En Barbiani Elia (Ed.), Edilizia popolare a Venezia. Storia, politiche, realizzazioni dell'Istituto Autonomo per le Case Popolari della Provincia di Venezia. Milan: Electa, 1983. pp. 93-111.

${ }^{39}$ Dubbini, Renzo: "San Giuliano e San Giobbe”. En Zucconi, Guido (Ed.): La grande Venezia. Una metropoli incompiuta tra Otto e Novecento. Venice: Marsilio, 2002. pp. 111-117.

${ }^{40}$ Benevolo, Leonardo: Un consuntivo delle recenti esperienze urbanistiche italiane. Casabella-Continuità, $\mathrm{N}^{\circ} 242$. August 1960. p. 33

${ }^{41}$ Ibid, p. 32.

${ }^{42}$ Colquhoun, Alan: Formal and Functional Interactions: A Study of Two Late Projects by Le Corbusier. Architectural Design. May 1966. p. 221.

${ }^{43}$ Benevolo, Leonardo: Un consuntivo delle recenti esperienze urbanistiche italiane. Casabella-Continuità, $\mathrm{N}^{\circ} 242$, August 1960. p. 33.

${ }^{44}$ L.S.: Il concorso per il quartiere residenziale alle Barene di S. Giuliano, Venezia-Mestre. Casabella-Continuità, $\mathrm{N}^{\circ} 242$, August 1960. p. 32.
} 


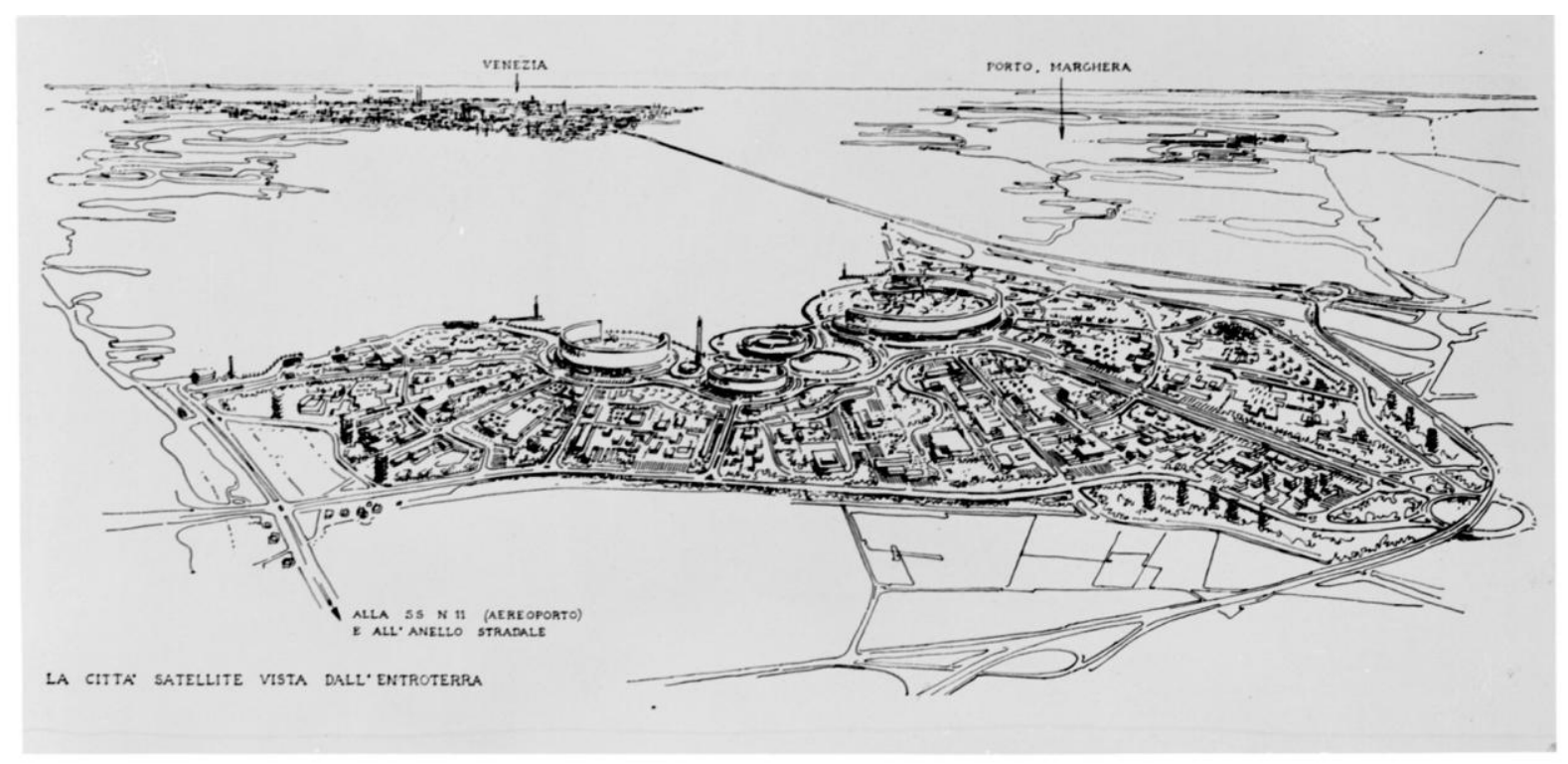

1. Ludovico Quaroni and collaborators, Project for the San Giuliano district (competition submission), 1959. Samonà 3.fot/1/080, Archivio Progetti Iuav, Venice.
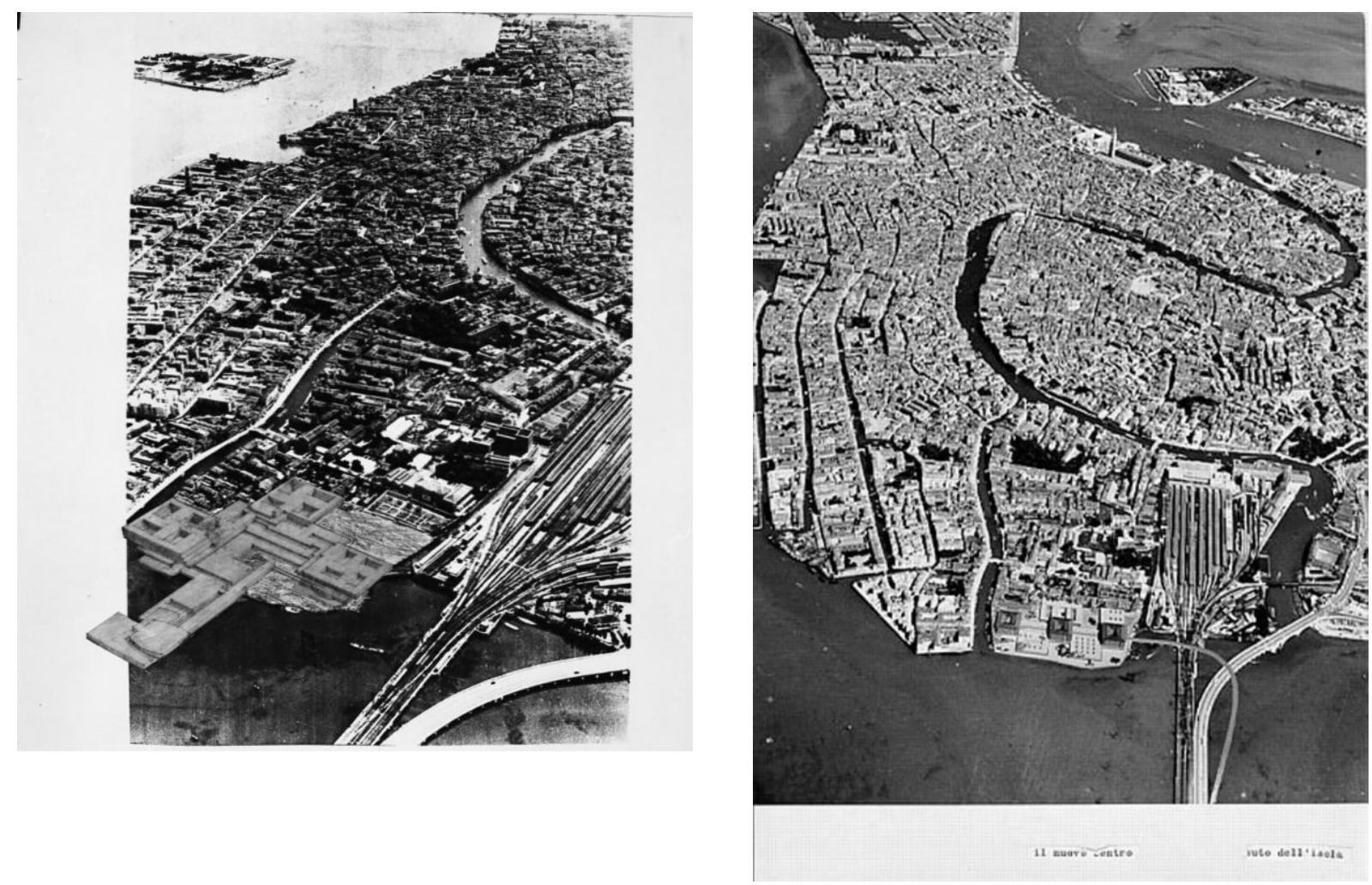

2. Romano Chirivi and collaborators, Project for the new Civic Hospital (competition submission), APriproduzioni/fot/015/12, Archivio Progetti Iuav, Venice.

3. Daniele Calabi and Mario Dalla Costa, Project for the new Civic Hospital (competition submission), APriproduzioni/fot/025/22, Archivio Progetti Iuav, Venice.

Another competition for Venice was held between May 20 and August 20, 1963 ${ }^{45}$. The competition for the new Hospital was made mandatory by the impossibility of the existing one, located on San Zanipolo, to adequately satisfy the growing health care standards. The problem was as old as the hospital itself: in fact, it was since 1807, when Scuola Grande di San Marco and the Dominican convent of Santi Giovanni e Paolo as well as the

${ }^{45}$ Ospedali Civili Riuniti: I progetti preliminari per il nuovo ospedale di Venezia. Venezia: Stamperia di Venezia, 1964. s.p. 
Ospedale dei Mendicanti were transformed into hospitals, that the institution was fighting with the inadequacy of its buildings and a lack of space ${ }^{46}$. In 1962 Carlo Ottolenghi became the president of the Ospedali Civili Riuniti and engaged himself in the attempt to demonstrate that the new administration had "cultural openness and organizational skills ${ }^{, 47}$ necessary to finally solve a century long problem. The competition produced an ambiguous result: out of a total of ten presented proposals, no first prize was assigned, two shared the second place and a special mention went to a third project. On one side, it can be assumed that the lack of a definitive result was due to the fact the at that time Hospital's administration had already established contacts with Le Corbusier inviting him to present a proposal. On the other, it is to be understand that at that moment at stake was not only the future of a single institution, but that of Venice as a whole ${ }^{48}$. Most of Jury's debates in fact focused not on the Hospital, but on the problem regarding the relationship between the historical center and modern architecture to be built not on terraferma, but within the city itself ${ }^{49}$.

The photo collages presented by the two second classified planners appear emblematic in exemplifying the impact that any new complex would have had for those arriving in Venice via the railway bridge. The first photo collage, presented by a group led by Romano Chirivi ${ }^{50}$, occupies the San Giobbe area with a cruciform shape. One of its wings stretches boldly towards the lagoon and would have produced an interesting dialogue with terraferma but in relation to Venice it did not present an "adequate scale" needed to be configured in relation to a regional health care system, thus reducing the number of beds and proposing to create other centers within the city and on terraferma. Services within the Hospital were organized in slabs, the highest of which were intended for hospitalization, while therapy and diagnostics occupied lower levels. The shape and the functional organization of this proposal have on some occasions even been indicated as elements Le Corbusier later used for his own project ${ }^{52}$.

The second proposal, designed by Daniele Calabi and Mario Dalla Costa, comprised two slabs hosting diagnostic and therapeutic functions, while concentrating hospitalization into three 20 meters high cubical volumes. The Jury considered it as an exceptionally good answer to Hospital's needs, but was unsatisfied with the architectural aspects of the proposal. As Bruno Zevi put it, "it hides a great organism [i.e., Venice] behind the facades of three irrelevant buildings ",53. Interpreting the results of this second competition, it might be said that although the competition offered some interesting proposals, it was the image of Venice that was not adequately taken in consideration neither in the first nor in the second project.

\footnotetext{
${ }^{46}$ Guidarelli, Gianmario; Tolic, Ines: "The history of the Civic Hospital in Venice (1797-2011) in the light of contemporary cultural and urban challenges”. En Calabi, Donatella (Ed.): Built city, designed city, virtual city, the museum of the city. Rome: CROMA, 2013. pp. 233-253.

${ }^{47}$ Mattioni, Emilio: "La vicenda del concorso preliminare per il nuovo ospedale di Venezia". En Talamone, Marida (Ed.): L'Italia di Le Corbusier (exhibition catalogue: Rome, October 18, 2012 - February, 17, 2013). Milan: Electa, 2012. p. 377.

${ }^{48}$ Zevi, Bruno: "Un'ospedale per Venezia. La macchina per guarire chiede Le Corbusier". En Zevi, Bruno: Cronache $e$ storia. Bari-Rome: Laterza, 1970. p. 303.

${ }^{49}$ Commissione giudicatrice concorso nuovo ospedale. Riunione 14-15 settembre 1963. Verbale 2. Nuovo Ospedale, M/41. Archivio Ospedale, Venezia.

${ }^{50}$ The group was formed by Romano Chirivi, Costantino Dardi, Emilio Mattioni, Valeriano Pastor and Luciano Semerani. Progetto per il Nuovo Ospedale Civile di Venezia (1963), AP-originali/pro/020, Archivio Progetti Iuav, Venezia.

${ }^{51}$ Zevi, Bruno: "Un'ospedale per Venezia. La macchina per guarire chiede Le Corbusier". En Zevi, Bruno: Cronache e storia. Bari-Rome: Laterza, 1970. p. 304.

${ }^{52}$ Tentori, Francesco: Imparare da Venezia: il ruolo futuribile di alcuni progetti architettonici veneziani dei primi anni Sessanta. Roma: Officina, 1994.

${ }^{53}$ Zevi, Bruno: “Un'ospedale per Venezia. La macchina per guarire chiede Le Corbusier”. En Zevi, Bruno: Cronache e storia. Bari-Rome: Laterza, 1970. p. 304.
} 
On October 29, 1963, the Municipality of Venice published a notice about another competition - an international one this time - for Tronchetto Island. The notice didn't conform to the rules for international architectural competitions inducing Pierre Vago, the secretary general of the International Union of Architects, to invite planners not to take part in it. Eventually, the notice was changed and the new international competition started on February 27, 1964. The competition notice asked planners "to pay attention to the habitat, to the landscape

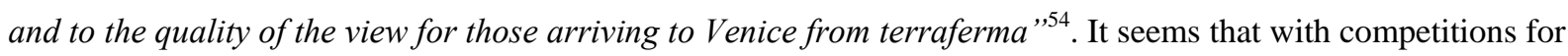
a new Hospital on one side and for Tronchetto on the other, Venice was determined to refurbish its main facade in a modern fashion but, again, no clear or definitive result was achieved: five proposals were awarded and one special mention was assigned. Moreover, due to certain freedom of interpretation that the notice left to competitors, planners presented very different proposals thus creating difficulties during the judging phase ${ }^{55}$.

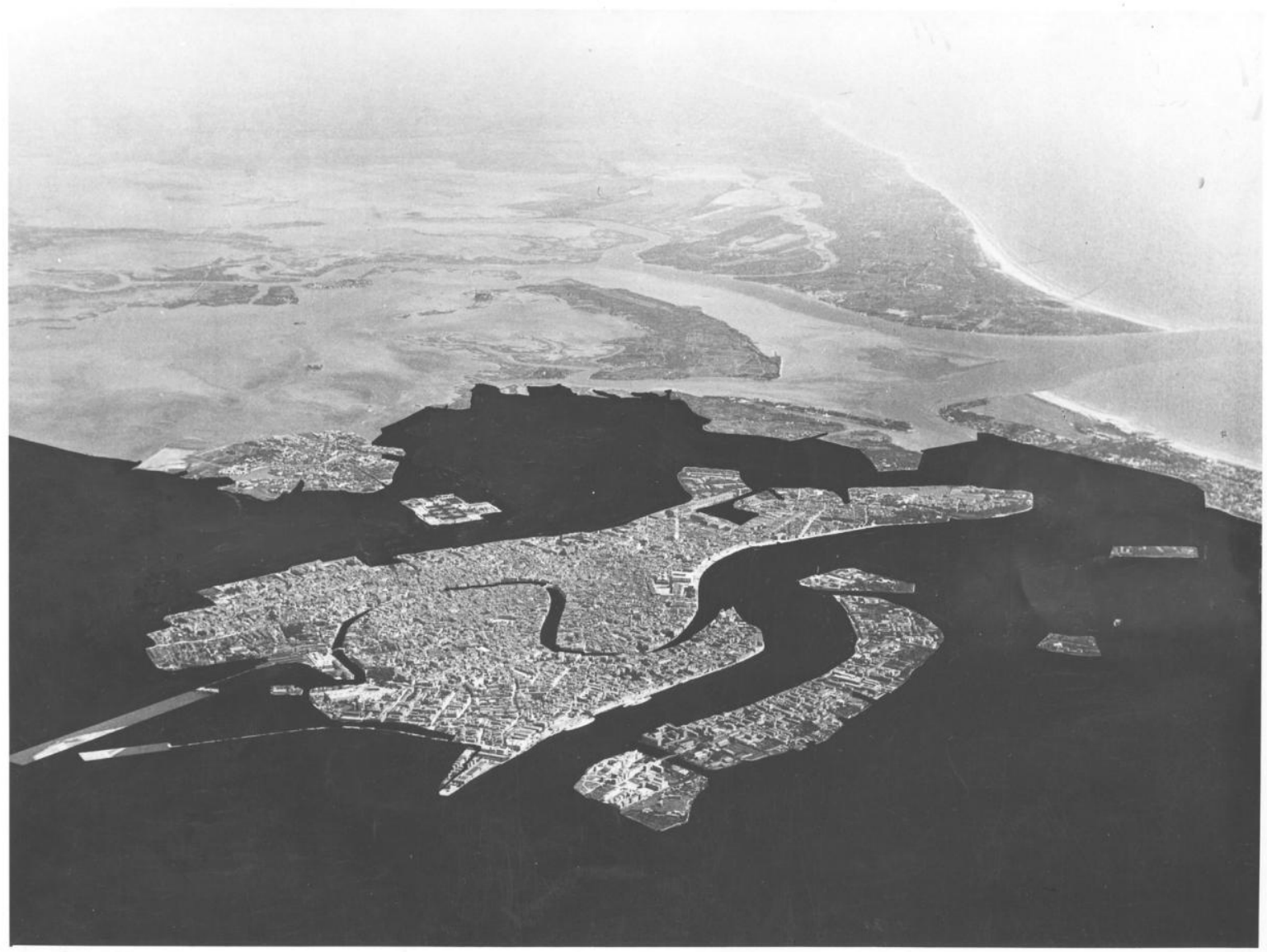

4. Giuseppe Samonà and collaborators, Project for the Tronchetto Island (competition submission), Trincanato 3. Attività professionale/1/049, Archivio Progetti Iuav, Venice.

Among the projects presented, one especially needs to be taken into consideration because of its radical answer to the problem of Venice. The proposal was presented with the name Novissime and was prepared by a group of

\footnotetext{
${ }^{54}$ Zevi, Bruno: "Lo sfregio di Venezia. Il Trinchetto istiga all'oscenità". En Zevi, Bruno: Cronache e storia. Bari-Rome: Laterza, 1970. p. 247.

${ }^{55}$ Concorso internazionale per il piano particolareggiato della nuova sacca del Tronchetto. Urbanistica. Rivista trimestrale dell'Istituto Nazionale di Urbanistica, nn. 42-43, February 1965, pp. 101-110.
} 
authors led by Giuseppe Samonà ${ }^{56}$. The project was based on the assumption that the most convenient choice for Venice would be to locate all the functions related to the commercial harbour not on Tronchetto Island (e.g. in Venice), but on terraferma. According to the planners, with this functional reorganization there would be no more need neither for the railway bridge nor for the highway which connect the city to mainland. Therefore, it was suggested to obliterate both, as well as the Tronchetto Island itself. The authors pushed the reasoning even further, suggesting that it was necessary to eliminate all the structures that were damaging the "true character" of Venice, bringing its form back to that that the city had in the 18th Century ${ }^{57}$. Instead of being labeled as reactionary, the project was judged as one of "the most controversial, most radical, [and] culturally the most brilliant" ever proposed for the city ${ }^{58}$. Within this proposal, "Venice rediscover[ed] its form and [found] therein all that it needs [...]" w9 while terraferma was to take over functions grown out of contemporary necessities. Obliging the historical center to stop its evolution, authors have affirmed the impossibility of Venice to satisfy modern needs, making it become mandatory to look for its future within the regional context.

Projects presented for Venice around the time Le Corbusier was involved in the debates about city's future are to be intended as attempts to guide the expansion on terraferma creating the premises for a balanced growth of the city center in modern fashion. During these debates, Le Corbusier was asked by the Hospital administration to present a proposal for San Giobbe. Slowly but steadily, the Hospital monopolized public opinion's attention reframing the problem of Venice as an insular matter. In fact, as thoroughly demonstrated by Mahnaz Shah ${ }^{60}$, Le Corbusier looked for inspiration in the historical center where he "discovered the expense of the city of Venice, its structure and its light ${ }^{, 61}$. As such, the project did not seek for a dialogue with terraferma but is to be understood in relation to the historical urban tissue and is to be intended as a modern counterpart of Saint Mark Square. Le Corbusier's Hospital was presented to the public opinion as a courageous and innovative project, but if a wider chronological frame is taken into consideration it seems that within the local administration a conservative front prevailed, thus renouncing to solve the "problem of Venice" within a wider regional frame.

\section{Conclusions}

Italian architecture and urban design went through an extraordinary period between 1950s and 1970s, as it is testified by the amount of competitions, buildings, publications and debates. Passionately discussed in those years was the relationship between historical centers and new peripheries, a topic that interested all Italian cities among which Venice represented an particularly delicate case. Within only a dozen of years, the city witnessed four major competitions, some of which - if buildings were accomplished - would have resulted in radical alterations of its character. The masterplan opened the city to a regional dimension which initiated the debates

\footnotetext{
${ }^{56}$ Other members of the team included: Costantino Dardi, Emilio Mattioni, Valeriano Pastor, Gian Ugo Polesello, Alberto Samonà. Gigot and Luciano Semerani, Egle Trincanato. Novissime, Trincanato 3.attività professionale/2/23, Archivio Progetti Iuav, Venezia.

${ }^{57}$ Il concorso per l'Isola del Tronchetto: si invertano i risultati. L'architettura. cronache e storia, n. 110, anno X, dicembre 1964, p. 507.

${ }^{58}$ Concorso internazionale per la sistemazione dell'Isola del Trinchetto. L'architettura. Cronache e storia, n. 111, anno X, gennaio 1965, p. 596.

${ }^{59}$ Rossi, Aldo: Considerazioni sul concorso internazionale per il piano urbanistico della Nuova Sacca del Trinchetto a Venezia. Casabella-Continuità, $\mathrm{N}^{\circ} 293$, November 1964. p. 17.

${ }^{60}$ Shah, Mahnaz: Le Corbusier's Venice Hospital Project. An Investigation into its Structural Formulation. Farnham: Ashgate, 2013.

${ }^{61}$ Allard, Pablo: "Bridge over Venice. Speculations on Cross-fertilization of Ideas between Team 10 and Le Corbusier (after a Conversation with Guillermo Jullian de la Fuente". En Sarkis, Hashim (Ed.), Le Corbusier. Venice hospital and the Mat building revival. Munich: Prestel, 2002. p. 30.
} 
about its future, and subsequent competitions tried to define it within the larger territorial context. Le Corbusier suggested terraferma as the location for the new Hospital ${ }^{62}$, but given administration's preferences for the center, he decided to assume the historical urban tissue as a generative element of his proposal. This decision, only partially retraceable in projects presented for the above mentioned competitions, framed the "problem of Venice" within its insular dimension. In other words, Le Corbusier reaffirmed the actuality of Venice within modernity, but to a certain degree also its self-sufficiency within the regional context. As such, the Hospital project is to be understood not in relation to terraferma, but as the counterpart of Saint Mark Square on the North-Western front, i.d. on the area that has become the new access point to the city since the railway bridge was built in 1831. In fact, being seen as "a meditation about the possibilities of architecture in relation to a city fragile and complex as Venice is ",63, Le Corbusier's project positioned itself in-between the conservative and the modernist front, satisfying the aspirations of both those for whom Venice was to be preserved and those for whom it was to be adapted to contemporary needs.

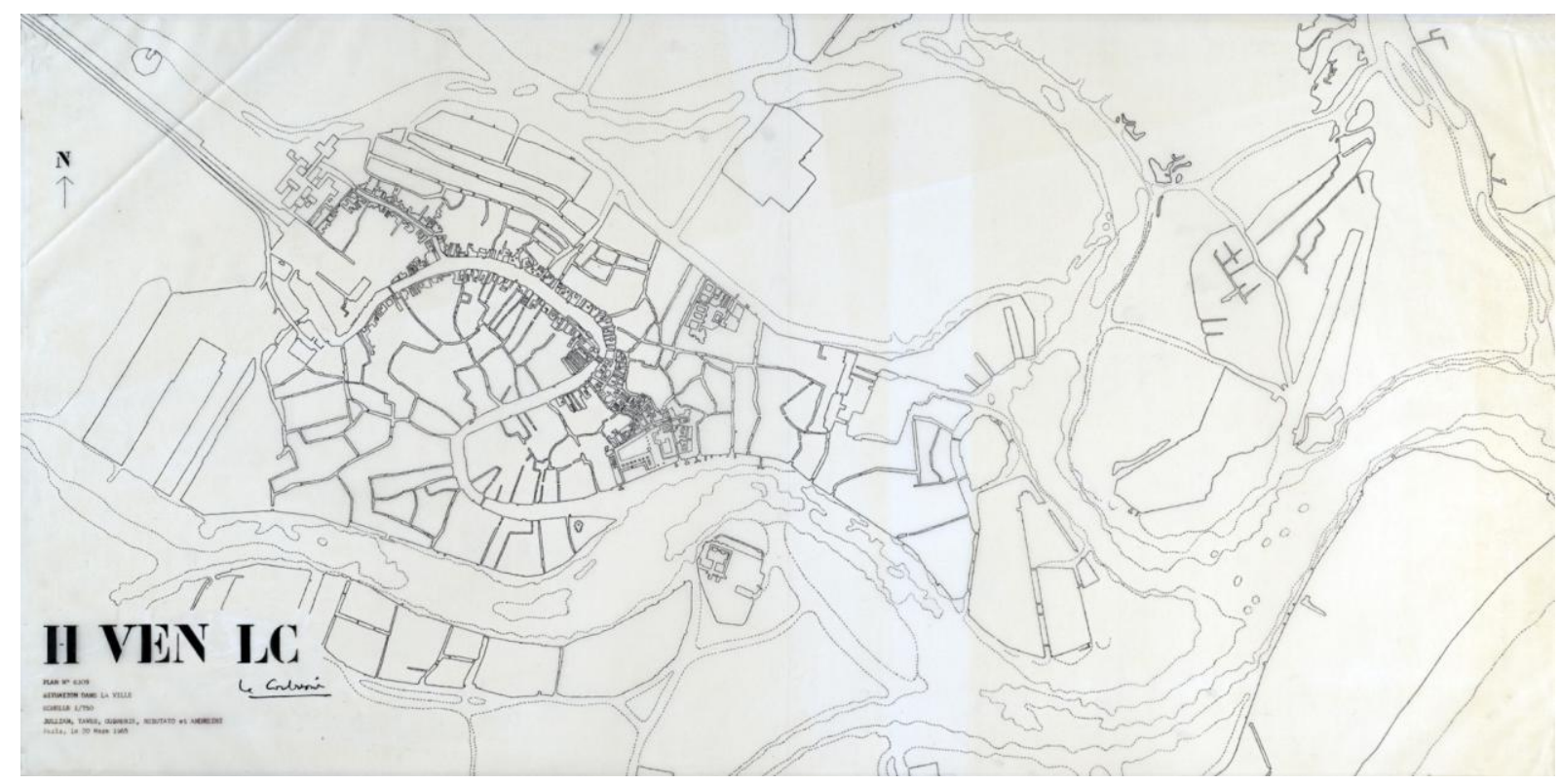

5. Le Corbusier, Situation dans la ville, Ospedale-pro/03/cartella 3/2, Archivio Progetti Iuav, Venice. (C) FLC-ADAGP

Eventually however, the story got two dramatic turns with Le Corbusier's death on August 27, 1965 and with the extraordinary aqua alta on Novem ber 4, 1966. On the second date, water invaded the city of Venice causing damages that reaffirmed the fragile nature of the ecosystem within which the historical center is located. After that tragic episode, the debates about Venice assumed a much lower tone, being hijacked towards protection and preservation of the existing, instead of focusing on the integration with terraferma and the consequent modernization. However, the final coup de grace to the Hospital project arrived at the end of 1970s, when the national health care system was finally reorganized on regional bases - thus reconfiguring the very context for which the project was initially conceived. Prized back then because of its relationship to Venice, ironically, the unaccomplishment of Le Corbusier's project was eventually determined by its unfitness to the regional dimension. For however it might be, between 1954 and 1966 Venice witnessed an extraordinary period

\footnotetext{
${ }^{62}$ Farinati, Valeria: Introduzione. En Farinati, Valeria (ed): H VEN LC Hôpital de Venise Le Corbusier. Inventario analitico degli Atti Nuovo Ospedale. Venezia: IUAV - AP Archivio Progetti, 1999, p. 51.

${ }^{63}$ Dubbini, Renzo: Trentacinque anni dopo. En Farinati, Valeria: H VEN LC Hôpital de Venise Le Corbusier. Inventario analitico degli Atti Nuovo Ospedale. Venezia: IUAV - AP Archivio Progetti, 1999, p. 30.
} 
catalyzing the interest of national and international audience and Le Corbusier was there where he has always been: at the epicenter of architectural debates.

\section{Bibliography}

Approvazione del Piano Regolatore Generale del Comune di Venezia. March 20, 1965. Consiglio Comunale. Archivio Storico di Venezia, Venezia.

Approvazione del primo elenco dei Comuni obbligati a redigere il piano regolatore dei rispettivi territori. Gazzetta Ufficiale della Repubblica Italiana. No 120. May 26, 1954. Rome: Istituto Poligrafico dello Stato.

Barbiani, Elia (Ed.), Edilizia popolare a Venezia. Storia, politiche, realizzazioni dell'Istituto Autonomo per le Case Popolari della Provincia di Venezia. Milan: Electa, 1983.

Benevolo, Leonardo: Un consuntivo delle recenti esperienze urbanistiche italiane. Casabella-Continuità, $\mathrm{N}^{\circ} 242$. August 1960.

Bodei, Silvia: Le Corbusier e Olivetti. La Usine Verte per il Centro di calcolo elettronico. Macerata: Quodlibet, 2014.

Calabi, Donatella (Ed.): Built city, designed city, virtual city, the museum of the city. Rome: CROMA, 2013.

Chirivi, Romano and others: Progetto per il Nuovo Ospedale Civile di Venezia (1963), AP-originali/pro/020, Archivio Progetti Iuav, Venezia.

Ciacci, Leonardo (Ed.): Venezia è una città. Un secolo di interpretazioni del cinema documentario. Venice: Marsilio, 2004.

Colquhoun, Alan: Formal and Functional Interactions: A Study of Two Late Projects by Le Corbusier. Architectural Design. May 1966.

Commissione giudicatrice concorso nuovo ospedale. Riunione 14-15 settembre 1963. Verbale 2. Nuovo Ospedale, M/41. Archivio Ospedale, Venezia.

Comune di Venezia; Fondazione Giorgio Cini: Atti del Convegno internazionale "Il problema di Venezia". Venice: w/o.pub, 1964.

Comune di Venezia: Concorso nazionale di idee per la impostazione del piano regolatore generale del Comune di Venezia. June 9, 1956. 1948/X-1-2. Archivio Storico Comunale, Venezia.

Comune di Venezia: Piano Regolatore Generale. Relazione. Venezia: w/o, 1959.

Concorso internazionale per il piano particolareggiato della nuova sacca del Tronchetto. Urbanistica. Rivista trimestrale dell’Istituto Nazionale di Urbanistica, NN42-43, February 1965.

Concorso internazionale per la sistemazione dell'Isola del Trinchetto. L'architettura. Cronache e storia, $\mathrm{N}^{\circ} 111$, X, January 1965.

Consiglio Comunale: Resoconto Stenografico della Seduta. Relazione Dorigo. February 14, 1958. Archivio Storico Comunale, Venezia.

Elementi per il concorso internazionale per il piano urbanistico. February 22, 1954. 1948/X-1-2. Archivio Storico Comunale, Venezia.

Farinati, Valeria (Ed.): H VEN LC Hôpital de Venise Le Corbusier. Inventario analitico degli Atti Nuovo Ospedale. Venezia: IUAV - AP Archivio Progetti, 1999.

Gresleri, Giuliano; Gresleri, Glauco: Le Corbusier. Il programma liturgico. Bologna: Compositori, 2001.

Il concorso per l'Isola del Tronchetto: si invertano $i$ risultati. L'architettura. cronache e storia, $\mathrm{N}^{\circ} 110, \mathrm{X}$, December 1964. 
L.S.: Il concorso per il quartiere residenziale alle Barene di S. Giuliano, Venezia-Mestre. Casabella-Continuità, $\mathrm{N}^{\circ} 242$, August 1960.

Ministero dei lavori pubblici: Quartieri coordinati. Rome: Editalia, 1960.

O’Byrne Orozco, María Cecilia. El proyecto para el hospital de Venecia de Le Corbusier. Director: Josep Quetglas. Universidad Politécnica de Cataluña, Escuela Superior de Arquitectura de Barcelona, 2007.

Ospedali Civili Riuniti: I progetti preliminari per il nuovo ospedale di Venezia. Venezia: Stamperia di Venezia, 1964.

Provvedimenti per la salvaguardia del carattere lagunare e monumentale di Venezia attraverso opere di risanamento civico e di interesse turistico. Gazzetta Ufficiale della Repubblica Italiana. No 103. April 28, 1956. Rome: Istituto Poligrafico dello Stato.

Puppi, Lionello; Romanelli, Giandomenico (Ed.): Le Venezie possibili: da Palladio a Le Corbusier. Milan: Electa, 1985.

Relazione del Sindaco Avv. Roberto Tognazzi nella seduta del 26 ottobre 1956 sul programma dell'Amministrazione Comunale per il quadriennio 1956-1960. Consiglio Comunale. Archivio Storico Comunale, Venezia.

Rossi, Aldo: Considerazioni sul concorso internazionale per il piano urbanistico della Nuova Sacca del Trinchetto a Venezia. Casabella-Continuità, N²93, November 1964.

Samonà, Giuseppe and others: Novissime, Trincanato 3.attività professionale/2/23, Archivio Progetti Iuav, Venezia.

Sarkis, Hashim (Ed.), Le Corbusier. Venice hospital and the Mat building revival. Munich: Prestel, 2002.

Settis, Salvatore: Se Venezia muore. Torino: Einaudi, 2014.

Shah, Mahnaz: Le Corbusier's Venice Hospital Project. An Investigation into its Structural Formulation. Farnham: Ashgate, 2013.

Talamone, Marida (Ed.): L'Italia di Le Corbusier (exhibition catalogue: Rome, October 18, 2012 - February, 17, 2013). Milan: Electa, 2012.

Tentori, Francesco: Imparare da Venezia: il ruolo futuribile di alcuni progetti architettonici veneziani dei primi anni Sessanta. Roma: Officina, 1994.

Zevi, Bruno: Cronache e storia. Bari-Rome: Laterza, 1970.

Zucconi, Guido (Ed.): La grande Venezia. Una metropoli incompiuta tra Otto e Novecento. Venice: Marsilio, 2002. 